\title{
Kompres hangat jahe pada pasien asam urat: Kegiatan Pengabdian kepada masyarakat di Endang Rejo Kecamatan Seputih Agung Lampung Tengah
}

\author{
Rika Yulendasari'; Jemy sundoro ${ }^{2 *}$, Usastiawaty Cik Ayu Saadiah Isnainy ${ }^{3}$ \\ Program Studi Ilmu Keperawatan Universitas Malahayati
}

Corresponding Author: Jemy sundoro, Mahasiswa Program Profesi Ners Universitas Malahayati

Email: jimifu658@gmail.com

\begin{abstract}
Abstrak. Pada tahun 2018, prevalensi penyakit sendi di Lampung berada pada urutan ke-12 di Indonesia yaitu sebesar 7,2 persen. Terapi nonfarmakologi untuk mempercepat proses penyembuhan pada pasien hiperurisemia yaitu terapi herbal, hemeopati, akupuntur, akupresur, terapi nutrisi, refleksologi, terapi garam, dan yoga. Salah satunya terapi herbal, Pengobatan dilakukan secara dini agar tidak terjadi kerusakan sendi ataupun komplikasi lain, pengobatan asam urat bertujuan menghilangkan keluhan nyeri sendi dan peradangan dengan obat-obat yaitu pemberian kompres hangat jahe. Tujuan setelah penyuluhan dan demonstrasi, diharapkan pemberian kompres hangat jahe dapat untuk menurunkan rasa nyeri pada pasien Asam urat. Adapun kegiatan yang dilakukan berupa penyuluhan menggunakan leaflet dan demonstrasi kompres hangat jahe. Terdapat penurunan nyeri pada pasien asam urat setelah pemberian kompres hangat jahe selama 3 hari di Kecamatan seputih agung Desa Endang Rejo, Lampung Tengah. Dengan demikian, pemberian kompres hangat jahe pada pasien asam urat sangat efektif dalam menurunkan nyeri.
\end{abstract}

Kata kunci: Kompres hangat, Asam urat, Nyeri

Abstract: In 2018, the prevalence of joint disease in Lampung ranks 12th at Indonesia (7.2 percent). Nonpharmacological therapy to accelerate the healing process in hyperuricemia patients, namely herbal therapy, hemeopathy, acupuncture, acupressure, nutritional therapy, reflexology, salt therapy, and yoga. One of them is herbal therapy, treatment is done early so that no joint damage or other complications occur, gout treatment aims to eliminate complaints of joint pain and inflammation with drugs that is giving warm compresses of ginger. The purpose after counseling and demonstration, it is expected that the provision of warm ginger compresses can reduce pain in gout patients. The activities carried out in the form of counseling using leaflets and demonstrations of warm compresses of ginger. There was a decrease in pain in gout patients after giving warm ginger compresses for 3 days at seputih agung Endang Rejo, Central Lampung. Thus, the administration of warm ginger in patients with gout is very effective in reducing pain.

Keywords: Warm compresses, Gout, Pain

\section{Pendahuluan}

Asam urat adalah bahan normal yang terdapat di dalam tubuh dan merupakan hasil akhir dari metabolisme purin, yaitu hasil degradasi dari purin nukleotida yang merupakan bahan penting di dalam tubuh sebagai komponen dari asam nukleat (Setiati, 2014). Asam urat adalah molekul yang 
relatif tidak larut dan dengan mudah mengendap dari larutan seperti urine atau cairan sinovial. Pada konsentrasi ion hidrogen fisiologis, asam urat terutama berada dalam bentuk terionisasi dan berada dalam plasma dalam bentuk natrium urat. Peningkatan kadar urat serum dikenal sebagai hiperurisemia (Gaw, 2012; Utami, 2019).

Di dunia prevalensi penyakit asam urat mengalami kenaikan jumlah penderita hingga dua kali lipat antara tahun 1990-2010. Pada orang dewasa di Amerika Serikat penyakit asam urat mengalami peningkatan dan mempengaruhi 8.3 juta (4\%) orang Amerika. Sedangkan prevalensi hiperurisemia juga meningkat dan mempengaruhi 43.300 .000 (21\%) orang dewasa di Amerika Serikat (Jaliana, dkk, 2018; Songgigilan, Rumengan \& Kundre, 2019).

Menurut data dari WHO penderita gangguan sendi di Indonesia mencapai $81 \%$ dari populasi, yang pergi ke dokter hanya $24 \%$ sedangkan yang langsung mengkonsumsi obat pereda nyeri yang di jual secara bebas hanya $71 \%$. Angka tersebut menempatkan Indonesia sebagai negara tertinggi menderita gangguan sendi apabila di bandingkan dengan negara lain. Apabila di dalam negeri penyakit asam urat menjadi ancaman tertinggi maka dari itu untuk skala Internasional berdasarkan survei WHO, Indonesia merupakan negara terbesar di dunia yang penduduknya menderita penyakit asam urat. Penyakit asam urat di sebut artritis gout termasuk penyakit degeneratif yang menyerang persendian, paling sering di jumpai di kalangan masyarakat terutama di alami pada lansia. Kejadian tingginya penyakit asam urat baik itu di negara maju maupun di negara berkembang semakin meningkat terutama pada pria yang berusia 40-50 tahun. Hal ini terjadi karena pria tidak mempunyai hormon estrogen yang dapat membantu pembuangan asam urat. Sedangkan pada wanita mempunyai hormon estrogen yang dapat membantu pembuangan asam urat lewat urine. Namun setelah hormon estrogen menurun (masa menopause) kadar asam urat pada wanita akan mengalami peningkatan (Depkes RI, 2017).

Berdasarkan Riset Kesehatan Dasar (RISKESDAS) pada tahun 2018 diketahui prevalensi penyakit sendi di Indonesia berdasarkan diagnosis tenaga kesehatan yaitu 13,3\% dan berdasarkan diagnosis dan gejala yaitu $18.9 \%$. Sedangkan berdasarkan daerah diagnosis tenaga kesehatan, tertinggi Aceh (13,3\%), diikuti Bengkulu (13,0\%) dan Bali (12,7\%). Pada tahun 2018, prevalensi penyakit sendi di Lampung berada pada urutan ke-12 di Indonesia yaitu sebesar 7,2\% (KEMENKES RI, 2018).

Asam urat merupakan hasil metabolisme purin didalam tubuh yang kadar tidak boleh berlebih. Fak-tor pemicu adalah makanan dan senyawa lain yang banyak mengandung protein. Penatalaksanaan diet untuk asam urat masalah diet rendah purin (Kowalak, 2011). Gejala nyeri yang dirasakan penderita dapat menyebabkan perubahan fisiologis yang berpengaruh terhadap penampilan fisik da menu-runnya fungsi tubuh pada kehidupan sehari-hari. Penderita Asam urat dapat mengalami gangguan mobilitas fisik, gangguan tidur, bahkan gangguan interaksi sosial. Sehingga hal tersebut perlu mendapat pena-nganan segera.

Menurut Sutriani (2008) mengemukakan bahwa terapi nonfarmakologi atau terapi komplementer alternatif untuk mempercepat proses penyembuhan pada pasien hiperurisemia yaitu terapi herbal, hemeopati, akupuntur, akupresur, terapi nutrisi, refleksologi, terapi garam, dan yoga (Sutriani et all, 2008 ; Rahmah, 2017). Salah satunya terapi herbal, Pengobatan dilakukan secara dini agar blm tidak terjadi kerusakan sendi ataupun komplikasi lain, pengobatan asam urat bertujuan menghilangkan keluhan nyeri sendi dan peradangan dengan obat-obat (Aru, 2010; Zahroh \& Faiza, 2018). Hal ini sesuai penelitan Wurangian, Bidjuni, \& Kallo (2014) terhadap 30 orang di Puskesmas Bahu Manado menyimpulkan kompres hangat dapat menurunkan skala nyeri pada penderita gout.

Pemberian kompres hangat merupakan mekanisme penghambat reseptor nyeri pada serabut saraf besar dimana akan mengakibatkan terjadinya perubahan mekanisme yaitu gerbang yang akhirnya dapat memodifidikasi dan merubah sensasi nyeri yang datang sebelum sampai ke korteks 
serebri menimbulkan persepsi nyeri dan reseptor otot sehingga nyeri dapat berkurang. Selain itu, terapi non farmakologis yaitu menggunakan tanaman jahe (Zingiber Officinale) (Wijayakusuma, 2006; Madoni 2018).

Jahe (Zingiber Officinale) merupakan salah satu tanaman dengan akar atau batang bawah digunakan untuk kebutuhan kuliner maupun pengobatan (Vallerie, 2009). Dalam pengobatan tradisional Asia, jahe dipakai untuk mengobati selesma, batuk, diare dan penyakit radang sendi seperti arthritis (Nulfitri, 2013).

Hal ini terbukti dalam penelitian Rusnoto, Cholifah \& Retnosari (2015) terhadap 30 orang di Desa Kedungwungu Kecamatan tegowanu Kabupaten Grobongan. Hasil penelitian diperoleh bahwa ratarata skala nyeri sebelum dilakukan kompres hangat memakai jahe adalah 6.00 (nyeri sedang), setelah dilakukan kompres hangat memakai jahe adalah 3,67 (nyeri ringan) setelah dilakukan selama 3 hari. Serta penelitian Rahayu, Budiharto \& Herman (2018) terdapat pengaruh kompres hangat jahe terhadap nyeri pada penderita asam urat.

Peran perawat dalam pemberian asuhan keperawatan membantu penderita asam urat untuk mempertahankan kadar asam urat pada tingkat normal dan meningkatkan kualitas kehidupan secara maksimal dengan cara memberi intervensi asuhan keperawatan sehingga dapat memperbaiki kondisi kesehatan penderita.

Desa Endang Rejo Kecamatan Seputih Agung Lampung Tengah dipilih menjadi tempat pelaksanaan kegiatan penyuluhan kesehatan tentang asam urat dan demontrasi tentang pemberian kompres hangat jahe dengan pertimbangan karena keluarga saya sendiri memiliki masalah kesehatan asam urat tinggi, dimana tujuan umum dalam kegiatan diharapkan pemberian kompres jahe hangat dapat menurunkan nyeri pada klien asam urat. Dan tujuan khusus dalam kegiatan yaitu asuhan keperawatan, telaah jurnal untuk menentukan intervensi, evaluasi hasil aplikasi intervensi, perbandingan hasil intervensi pemberian kompres hangat jahe.

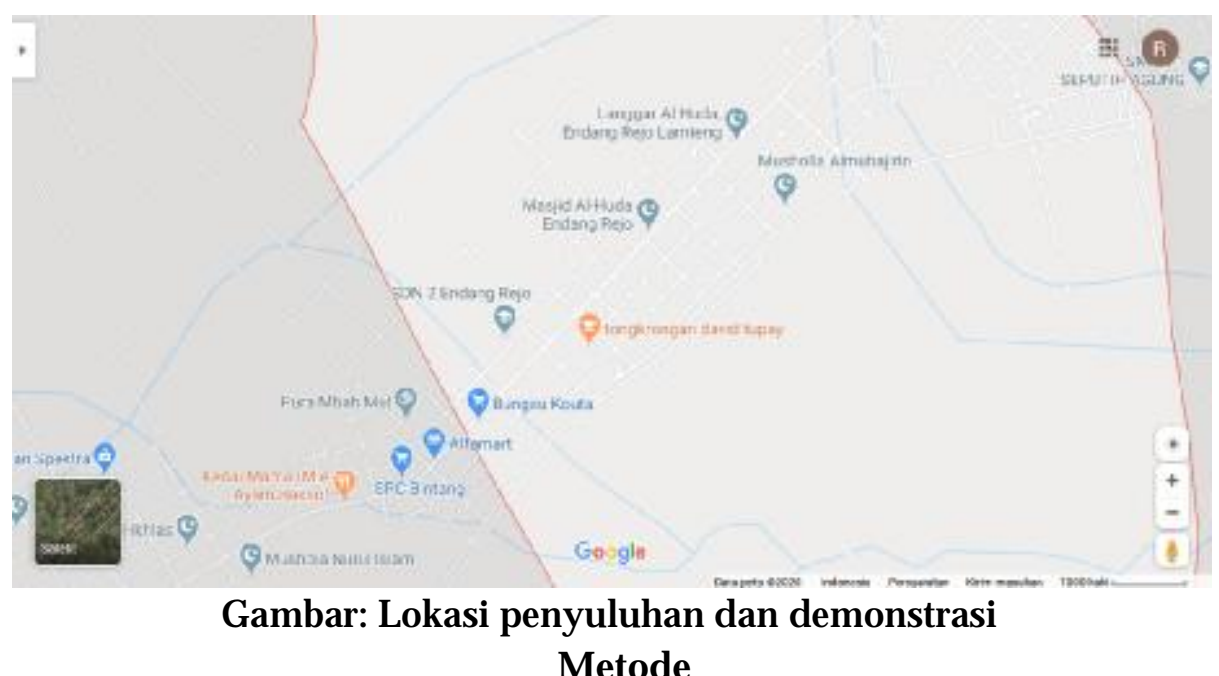

Tahap persiapan dari kegiatan adalah pembuatan pre planning, persiapan penyajian leaflet dan demostrasi, tempat dan alat-alat lainnya disiapkan oleh peneliti. Pembuatan leaflet dibuat pada hari sabtu 06 Juni 2020, pada tanggal 07 juni 2020 dilakukan penyuluhan, pengecekan asam urat, dan demostrasi kompres hangat jahe.

Kegiatan ini dengan pemberitahuan kepada klien. Dan dilanjutkan penyuluhan penyuluhan, pengecekan asam urat, dan demostrasi kompres hangat jahe. Peserta hadir 1 orang yaitu perempuan. 
Setting tempat sudah sesuai dengan rencana dan perlengkapan yang dilakukan untuk penyuluhan sudah tersedia dan sudah digunakan sebagaimana mestinya. Peran peneliti sebagai modertor, notulen, observer, dan juga fasilitator. Penggunaan bahasa yang dipraktekkan sudah komunikatif dalam penyampaianya, klien dapat memahami dan dapat mempraktekkan kembali yang di demonstrasikan.

Pelaksanaan kegiatan dilaksanakan pukul 09.00 s/d 09.30 WIB. Sesuai dengan jadwal yang sudah ditentukan. Klien dapat memahami dan mengerti tentang pengertian terapi pemberian kompres hangat jahe. Klien dapat memahami dan mengerti tentang tujuan dilakukannya terapi pemberian kompres hangat jahe. Klien dapat memahami dan mengerti tentang manfaat dan teknik pembuatan terapi pemberian kompres hangat jahe. Klien dapat memahami dan mengerti tentang langkah-langkah pembuatan kompres hangat jahe

\section{Hasil dan Pembahasan}

Pelaksanaan pemberian terapi pembuatan teh dilaksanakan pada tanggal 07 Mei 2020 s/d 09 Mei 2020. Penelitian dilakukan selama 3 hari, setelah dilakukan nya pemberian terapi selama 3 hari menurunkan nyeri klien. Berikut gambar pelaksanaan penyuluhan, pengecekan kadar asam urat dan pemberian terapi pemberian kompres hangat jahe:
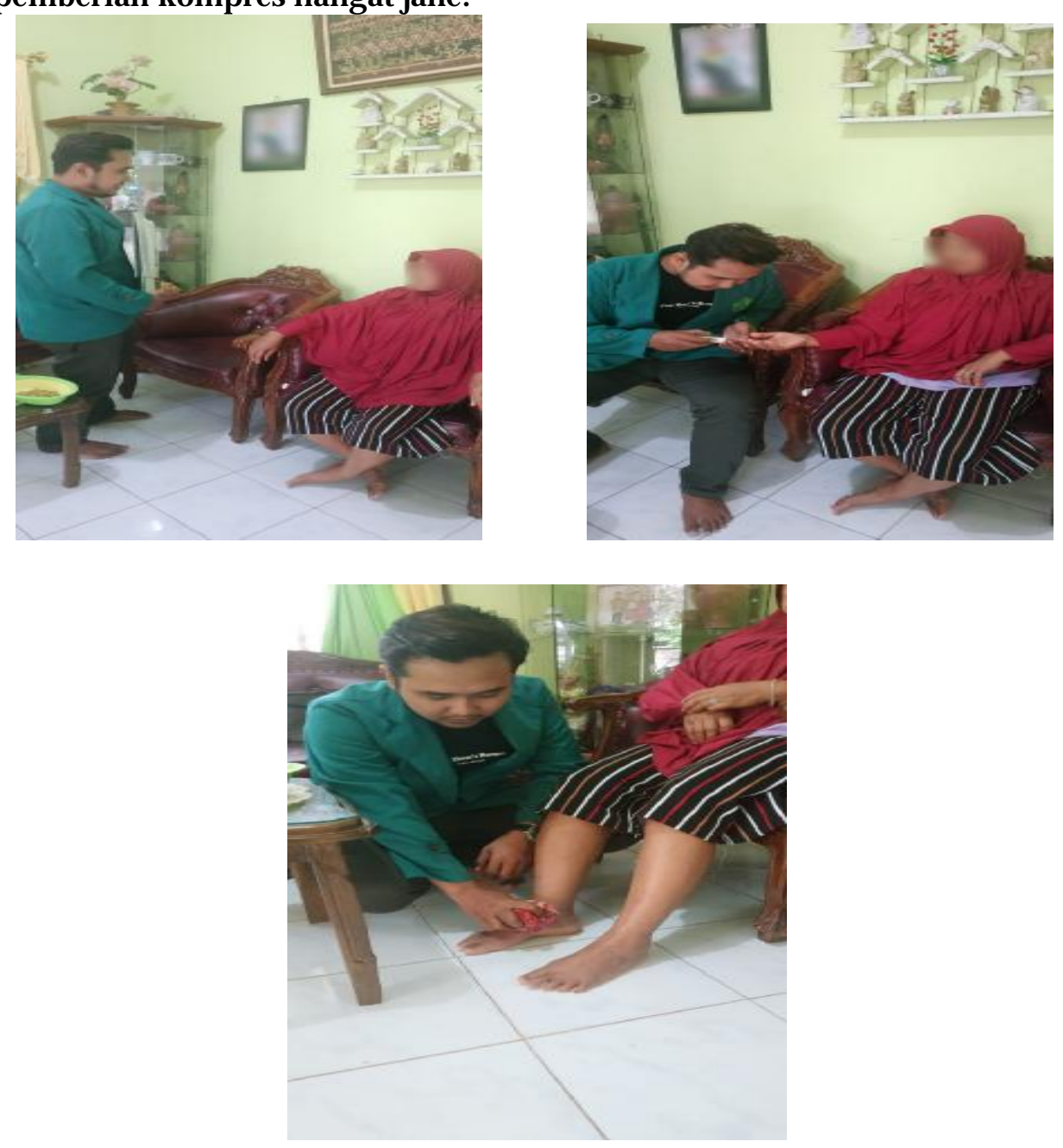

Gambar 4.1 pelaksanaan penyuluhan, pengecekan kadar asam urat dan pemberian terapi kompres hangat jahe 
Tabel 1 Evaluasi Tabel Penurunan Nyeri Asam Urat

\begin{tabular}{ccccc}
\hline \multirow{2}{*}{ Nama Klien (Inisial) } & \multicolumn{4}{c}{ Kadar Asam Urat } \\
\cline { 2 - 5 } & $\begin{array}{c}\text { Sebelum diberikan } \\
\text { terapi }\end{array}$ & Hari ke1 & Hari ke 2 & Hari ke 3 \\
\cline { 2 - 5 } & 6 & 6 & 4 & 3 \\
\hline Tn. M & 5 & 5 & 4 & 3 \\
\hline Ny. Y & & &
\end{tabular}

Pada tabel 1 dapat dilihat evaluasi hari terakhir pemeriksaan kadar asam urat terjadi penurunan antara klien 1 Tn.M, klien 2 Ny. Y dan, diperoleh data pada klien 1 Tn.M Intensitas nyeri asam urat sebelum diberikan asuhan keperawatan yaitu kadar asam urat: 6. Pada klien 2 Ny.Y intensitas nyeri asam urat sebelum diberikan asuhan keperawatan yaitu intensitas asam urat:5, Hasil penelitian ini sesuai dengan penelitian sebelumnya yang dilakukan oleh Oktari R.D (2018) tentang Pengaruh kompres hangat rebusan air serai (cymbogon nardus) terhadap penurunan nyeri hiperuresemia pada lansia di posyandu lansia di dusun sendangrejo desa banjardowo jombang. Asam urat adalah penyakit metabolik yang ditandai dengan penumpukan asam urat yang nyeri pada tulang sendi, sangat sering ditemukan pada kaki bagian atas, pergelangan dan kaki bagian tengah. Asam urat merupakan penyakit metabolik yang ditandai oleh penumpukan asam urat yang menyebabkan nyeri sendi pada sendi. Asam urat merupakan kelompok keadaan heterogeus yang berhubungan dengan efek genetik pada metabolisme purin atau hiperuricemia (Komariah.A,2015).

Pada klien 1 Tn.M setelah diberikan intervensi kompres hangat rebusan serai selama kurun waktu 3 (tiga) hari, dari hasil pemeriksaan didapatkan penurunan nyeri asam urat pada hari ke 1 (pertama): 6, pada hari ke 2 (dua): 4, pada hari ke 3 (tiga): 3. Pada klien 2 Ny.Y setelah intervensi kompres hangat rebusan serai selama kurun waktu 3 (tiga) hari, dari hasil pemeriksaan didapatkan penurunan nyeri asam urat pada hari ke 1 (pertama): 5, pada hari ke 2 (dua): 4, pada hari ke 3 (tiga): 3.Hasil penelitian ini sesuai dengan penelitian sebelumnya yang dilakukan oleh Oktari R.D,2018 tentang Pengaruh kompres hangat rebusan air serai (cymbogon nardus) terhadap penurunan nyeri hiperuresemia pada lansia di posyandu lansia di dusun sendangrejo desa banjardowo jombang.

Terdapat perbedaan rata - rata kadar asam urat sebelum dan sesudah diberikan kompres hangat rebusan serai yaitu pada klien 1 Tn.M selisih intensitas nyeri asam urat sebelum diberikan terapi kompres hangat rebusan serai yaitu 6 dan sesudah diberikan terapi kompres hangat rebusan serai selama 3 (tiga) hari yaitu 3, pada klien 2 Tn.Y selisih intensitas nyeri asam urat sebelum diberikan terapi kompres hangat rebusan sera yaitu 5 dan sesudah diberikan terapi kompres hangat rebusan serai selama 3 (tiga) hari yaitu 3.Dari hasil selisih penurunan intensitas nyeri asam urat pada klien 1 Tn.M, klien 2 Ny Y,didapatkan penurunan intnsitas nyeri asam urat pada klien 1 Tn.M yaitu 3, sedangkan penurunan intensitas nyeri asam urat paling banyak terjadi pada klien $2 \mathrm{Ny}$. Y yaitu 3.

Penyebab utama terjadinya asam urat adalah karena adanya deposit penimbunan Kristal asam urat dalam sendi. Penimbunan asam urat sering terjadi pada penyakit dengan metabolisme asam urat abnormal dan kelainan metabolik dalam pembentukan purin dan ekskresi asam urat yang kurang dari ginjal. Beberapa faktor lain yang mendukung seperti faktor genetik yaitu gangguan metabolisme purin yang menyebabkan asam urat berlebihan (hiperuricemia), retensi asam urat atau keduanya. (Annisya, 2019).

Nyeri adalah gejala yang dapat di timbulkan pada penyakit Asam urat ditandai dengan nyeri pada tulang sendi, sangat sering ditemukan pada kaki bagian atas, pergelangan dan kaki bagian tengah. Asam urat merupakan penyakit metabolik yang ditandai oleh penumpukan asam urat yang 
menyebabkan nyeri sendi pada sendi. Asam urat merupakan kelompok keadaan heterogeus yang berhubungan dengan defek genetik pada metabolisme purin atau hiperuricemia (Priscilla, 2014).

Tanaman serai (Cymbogon nardus) merupakan tanaman dengan habitus terna perennial, serai adalah tanaman dari suku poaceace yang sering disebut dengan suku rumput-rumputan.Kompres hangat serai memberikan rasa hangat untuk memenuhi kebutuhan untuk rasa nyaman. Membebaskan atau mengurangi rasa nyeri dalam buku herbal Indonesia disebutkan bahwa khasiat tanaman serai mengandung astiri yang memiliki sifat kimiawi dan efek farmakologi yaitu rasa pedas dan bersifat hangat sebagai anti radang dan menghilangkan rasa sakit yang bersifat analgesik serta melancarkan sirkulasi darah, yang diindikasikan untuk menghilangkan nyeri otot, nyeri sendi, pada penderita hiperuresemia badan pegal linu dan sakit kepala.

\section{Kesimpulan}

Terapi non farmakologi pemberian kompres hangat jahe terbukti dapat menurunkan nyeri pada penderita asam urat. Hal ini membuktikan beberapa hasil penelitian yang pernah dilakukan kepada klien dengan asam urat, bahwa pemberian kompres hangat jahe dapat dijadikan alternatif perawatan asam urat yang murah, mudah, dan aman.

\section{Daftar Pustaka}

Brunner, L. S., Smeltzer, S. C. O., \& Suddarth, D. S. (2010). Brunner \& Suddarth's textbook of medical-surgical nursing; Vol. 1. Language, 27, 1114-2240p.

Depkes, R. I. (2017). Profil kesehatan republik indonesia. Jakarta: Badan Penelitian dan Pengembangan Kesehatan Kemenkes RI.

Digiulio, M., Jackson, D., \& Keogh, J. (2014). Keperawatan medikal bedah. Yogyakarta: Rapha Publishing.

Kemenkes, R. I. (2018). Hasil utama RISKESDAS 2018. Online) http://www. depkes. go. id/resources/download/infoterkini/materi_rakorpop_2018/Hasil\% 20Riskesdas, 202018.

Kowalak, J. P., Welsh, W., \& Mayer, B. (2011). Buku ajar patofisiologi. Jakarta: EGC, 519-521.

Madoni, A., \& Padang, S. I. Pengaruh Kompres Hangat Memakai Parutan Jahe Terhadap Penurunan Intensitas Nyeri Gout Arthritis Pada Lansia Di Wilayah Kerja Puskesmas Lubuk Begalung Tahun 2017.

Masyhurrosyidi, H., Kumboyono, K., \& Utami, Y. W. (2016). Pengaruh Kompres Hangat Rebusan Jahe Terhadap Tingkat Nyeri Subakut Dan Kronis Pada Lanjut Usia Dengan Osteoarthtritis Lutut Di Puskesmas Arjuna Kecamatan Klojen Malang Jawa Timur. Majalah Kesehatan Fkub, 1(1), 39-44.

Nurarif, A. H., \& Kusuma, H. (2015). Aplikasi asuhan keperawatan berdasarkan diagnosa medis \& Nanda NICNOC. Yogyakarta: MediAction.

Rahmah, A. (2017). Efektivitas pijat refleksi dan pijat tubuh terhadap asam urat darah dan skala nyeri pada pasien hiperurisemia di ciledug (Bachelor's thesis, UIN Syarif Hidayatullah Jakarta: Fakultas Kedokteran dan Ilmu Kesehatan, 2017).

Rusnoto, R., Cholifah, N., \& Retnosari, I. (2015). Pemberian Kompres Hangat Memakai Jahe Untuk Meringankan Skala Nyeri Pada Pasien Asam Urat di Desa Kedungwungu Kecamatan Tegowanu Kabupaten Grobogan. Jurnal Ilmu Keperawatan dan Kebidanan, 6(1).

Setiati, S., \& MEpid, S. P. (Eds.). (2014). Ilmu penyakit dalam. Interna Publishing. 
Songgigilan, A. M., Rumengan, I., \& Kundre, R. (2019). Hubungan Pola Makan Dan Tingkat Pengetahuan Dengan Kadar Asam Urat Dalam Darah Pada Penderita Gout Artritis Di Puskesmas Ranotana Weru. Jurnal Keperawatan, $7(1)$.

Tim Pokja, S. D. K. I. DPP PPNI.(2017). Standar Intervensi Keperawatan Indonesia. Jakarta Selatan: Dewan Pengurus Pusat Persatuan Perawat Nasional Indonesia.

Utami, T. (2019). Gambaran Kadar Asam Urat Pada Wanita Menopause Di Uptd Pelayanan Sosial Lanjut Usia Tresna Werdha Kecamatan Natar Lampung Selatan Tahun 2019 (Doctoral dissertation, Poltekkes tanjungkarang).

Wurangian, M., Bidjuni, H., \& Kallo, V. (2014). Pengaruh Kompres Hangat Terhadap Penurunan Skala Nyeri Pada Penderita Gout Arthritis Di Wilayah Kerja Puskesmas Bahu Manado. JURNAL KEPERAWATAN, 2(2).

Zahroh, C., \& Faiza, K. (2018). Pengaruh kompres hangat terhadap penurunan nyeri pada penderita penyakit Artritis Gout. Jurnal Ners dan Kebidanan (Journal of Ners and Midwifery), 5(3), 182-187. 